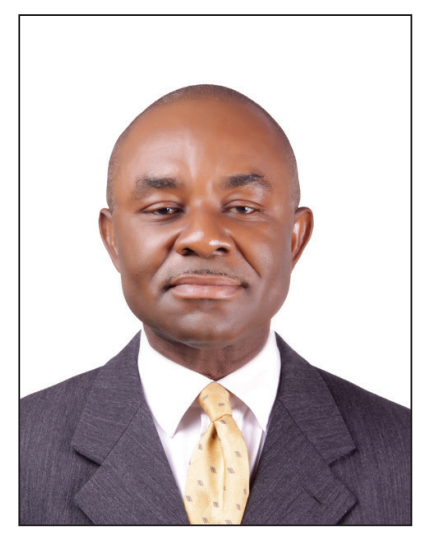

Michael Akpa Ajanwachuku,

PhD, Senior Lecturer in Law and former Dean,

Faculty of Law, Ebonyi State University,

Abakaliki, Nigeria

e-mail: hemenfaga@gmail.com

doi: 10.21564/2414-990x.138.108965

UDC 347.637

\title{
THE NIGERIAN CHILD'S RIGHTS ACT AND RIGHTS OF THE DISABLED CHILD: A NECESSITY OR SURPLUSAGE?
}

The rights of the Nigerian child are set out in the Child's Rights Act, 2003. The Act made specific provisions for the rights of the disabled child. This paper critically examines the relevance of these provisions in the light of other legislations in Nigeria. It finds that the provisions are a surplusage and counter-productive; they should therefore, be deleted.

Keywords: child's rights; disability; Nigeria; international instruments.

Айанвачуку M. A., доктор философии в области права, старший преподаватель, юридический факультет, Эбонийский государственный университет, Нигерия, г. Абакалики.

e-mail: hemenfaga@gmail.com

Закон о правах детей в Нигерии и права ребенка-инвалида: необходимость или излишество?

Права ребенка закреплень в Законе Нигерии о правах детей 2003 года. В Законе содержатся конкретные положения о правах ребенка-инвалида. Автор статьи подвергает критике актуальность этих положений в свете других законов Нигерии. Аргументируется, почему эти положения являются излишними и контрпродуктивными, и их следует исключить.

Ключевые слова: права детей; инвалидность; Нигерия; международные инструменты.

Introduction. The rights of the Nigerian child were provided for in different enactments in Nigeria that were not entirely made for children. These set of enactments include the Constitution of the Federal Republic of Nigeria; ${ }^{1}$ the Criminal

\footnotetext{
${ }^{1}$ Section 17(3)(f) provides for the obligation of Nigeria to direct its policy towards ensuring that children and young persons are protected against any exploitation, whatsoever, and against moral and material neglect.
} 
Code Act; ${ }^{1}$ the Penal Code Law; ${ }^{2}$ the Matrimonial Causes Act; ${ }^{3}$ the Labour Act; ${ }^{4}$ and so on. The first enactment that authoritatively recognized a child in Nigeria in terms of welfare and was entirely made for the Nigerian child, was the Children and Young Persons Ordinance $1943^{5}$.

After the existence of the Ordinance in 1943, came the need for a more recent single enactment. The need was actualized when the Child's Rights Act was enacted in 2003.

The Child's Right Act of Nigeria ${ }^{6}$ was enacted on the $31^{\text {st }}$ day of July, 2003 and was hilariously welcomed, as it was an answer to the clarion call for a comprehensive and recent enactment on the rights of the Nigerian child. ${ }^{7}$

The Act, made up of 278 sections of 24 parts with 11 schedules made provisions for several rights of the Nigerian child, for reason of which it has been described as "a milestone" ${ }^{\prime}$ and "a very ambitious legislation". ${ }^{9}$

The Act made specific provisions for the disabled child and attests to the Act as not only a milestone but a very ambitious legislation on the rights of the Nigerian child.

${ }^{1}$ Cap C38, Laws of the Federation of Nigeria, 2010 which respectively provides in sections 30 and 39 that a male child under the age of 12 cannot be convicted of the offence of unlawful carnal knowledge; and that a juvenile who has been convicted of the offence of treason by way of instigating invasion of Nigeria, a crime that is punishable by death, shall not so be punished, but shall be detained at the pleasure of the President.

${ }^{2}$ Law No. 89 Northern Laws of Nigeria, 1963 which provides in section 50(a) that a child under the age of 7 cannot be convicted of an offence.

${ }^{3}$ Cap M7, Laws of the Federation of Nigeria, 2010 which respectively provides in sections 70, 71 and 72 for the right of the child to maintenance; to welfare, advancement or education; and to settlement of property.

${ }^{4}$ Cap L1, Laws of the Federation of Nigeria, 2010 which respectively provides in sections 49(3); 51; $59(3) ; 60(2)$ and 61 for the right a young person above the age of twelve years and below the age of sixteen years to enter into a contract of apprenticeship; for the right of a child above twelve years who is an apprentice to be entitled to wages if retained after the agreed period of apprenticeship; for the right of a young person under the age of fourteen years to be employed on a daily wage, and on a day-to-day basis; for the right of a young person over the age of sixteen years to be employed during the night in some industrial undertakings or activities; and for the right of any person even under the age of fifteen years to be employed in vessels.

${ }^{5}$ The Children and Young Persons Ordinance, 1943 later became Chapter 31 of the Laws of Nigeria as revised in 1948 and was later retained as Chapter 32 of the Laws of the Federation of Nigeria and Lagos as revised in 1958. The Ordinance (now termed Act) was made applicable to Lagos in 1946, was extended to the Eastern and Western Regions of Nigeria by Ordinance-in-Council No. 22 of 1946 and was enacted for Northern Nigeria in 1958. On the adoption of state structure in 1967, many states enacted their own Children and Young Persons Laws which are identical to the original legislation. Having become state law the enactment was omitted in the Revised Editions of the Laws of the Federation of Nigeria, 1990, 2004 and 2010.

${ }^{6}$ Child's Rights Act, Cap C50, Laws of the Federation of Nigeria, 2010, hereinafter simply referred to as "the Act".

7 B.O. Igwenyi "A Comment on the Child Rights Act", Ebonyi State University Law Journal, Vol. 1, No. 1 October 2005, pp. 159-169.

${ }^{8}$ Ibid.

${ }^{9}$ Ibid. 
Commendable though it is, that the Act made specific provisions for the disabled child, the aim of this paper is to examine whether the specific provisions were necessary or a mere surplusage and further examine the effect of the specific provisions (if any), on the rights of the disabled child. This paper shall do so under the theoretical framework of the Specific Provisions of the Act, vis-a-vis Similar Provisions in Some International Instruments; the Need or otherwise for the Specific Provisions; Conclusion and Recommendation.

The Specific Provisions in the Act vis-a-vis Similar Provisions in Some International Instruments. The specific provisions in the Act have their equivalent in some international instruments, specifically, the United Nations Convention on the Rights of the Child, 1989 and the African Charter on the Rights and Welfare of the Child, 1990. Nigeria signed and ratified the Convention ${ }^{1}$ and signed the Charter ${ }^{2}$ long before the coming into existence of the Act, ${ }^{3}$ but the provisions of the international instruments do not apply in Nigeria because the instruments were not part of the domestic laws of Nigeria as provided for, under section 12 of the Constitution of Nigeria. ${ }^{4}$

The Act that was a ready substitute for the non-applicable Convention and the Charter, made provisions for the rights of disabled children, as the Convention and the Charter did.

A comparative analysis of the specific provisions in the Act, the Convention and the Charter shall now be made:

The Convention made specific provisions for the rights of disabled children in these words:

States Parties recognize that a mentally or physically disabled child should enjoy a full and decent life in conditions which ensure dignity, promote self-reliance, and facilitate the child's active participation in the community. ${ }^{5}$

However, according to the Convention, a disabled child shall enjoy the rights provided in the immediate preceding paragraph, "subject to available resources" or "whenever possible". From the Convention,

States Parties recognize the right of the disabled child to special care and shall encourage and ensure the extension, subject to available resources, to the eligible child and those responsible for his or her care, of assistance for which application is

\footnotetext{
${ }^{1}$ The Convention was adopted by the United Nations General Assembly on the $20^{\text {th }}$ day of November, 1989 and came into force on the $2^{\text {nd }}$ day of September, 1990. It was respectively signed and ratified by Nigeria on the $29^{\text {th }}$ day of January, 1990 and the $23^{\text {rd }}$ day of July, 2001.

${ }^{2}$ The Charter was adopted by the Organization of African Unity (African Union, with effect from the $9^{\text {th }}$ day of July, 2002) on the $1^{\text {st }}$ day, July 1990 and came into force on the $29^{\text {th }}$ day of November, 1999. It was signed by Nigeria on the $13^{\text {th }}$ day of July, 2001.

${ }^{3}$ The Act came into existence on the $31^{\text {st }}$ day, July, 2003.

${ }^{4}$ By the provision of section 12 of the Constitution of the Federal Republic of Nigeria, 1999, any international instrument that has not been enacted as an Act of the National Assembly shall not apply in Nigeria. The Convention and the Charter were not so enacted.

${ }^{5}$ The Convention, Article XXIII (1).
} 
made and which is appropriate to the child's condition and to the circumstances of the parents or others caring for the child. ${ }^{1}$

\section{And that}

Recognizing the special need of a disabled child, assistance extended ... shall be provided free of charge, whenever possible.... ${ }^{2}$

The Charter has a similar provision for the rights of disabled children and also has two subsequent provisions that restricted the enjoyment of the rights. The restriction is "subject to available resources", as provided for in the Convention but did not include "whenever possible" as provided for in the Convention. The provisions in the Charter are as follows:

Every child who is mentally or physically disabled shall have the right to special measures of protection in keeping with his physical and moral needs and under conditions which ensure his dignity, promote his self-reliance and active participation in the community. ${ }^{3}$

For the restrictions,

States Parties to the present Charter shall ensure, subject to available resources, to a disabled child and to those responsible for his care, of assistance for which application is made and which is appropriate to the child's condition and in particular shall ensure that the disabled child has effective access to training, preparation for employment and recreational activities in a manner conducive to the child achieving the possible social integration, individual development and his cultural and moral development. ${ }^{4}$

And that

The States Parties to the present Charter shall use their available resources, with a view to achieving progressively the full convenience of the mentally and physically disabled person to movement and access to public highway, buildings and other places to which the disabled may legitimately want to have access to. ${ }^{5}$

Just as the Convention and the Charter made specific provisions for the rights of a disabled child, the Act has such provisions. According to the Act, every child who is in need of special protection measures has the right to such measures of protection as is appropriate to his physical, social, economic, emotional and mental needs and under conditions which ensure his dignity, promote his self-reliance and active participation in the community. ${ }^{6}$

The Act made use of the expression "special protection measures" unlike the Convention and the Charter that employed the expression "mentally or physically disabled". However, the content of the provisions in the Act, particularly when compared with the similar provisions under the Convention and the Charter shows

\footnotetext{
${ }^{1}$ Ibid., Article XXIII (2). Underlining mine, for emphasis.

${ }^{2}$ Ibid., Article XXIII (3). Underlining mine, for emphasis.

${ }^{3}$ The Charter, Article XIII (1).

${ }^{4}$ Ibid., Article XIII (2). Underlining mine, for emphasis.

${ }^{5}$ Ibid., Article XIII (3). Underlining mine, for emphasis.

${ }^{6}$ The Act, section 16 (1).
} 
that the expression "special protection" means no less than "mentally or physically disabled". The Charter in the chapter heading of Article XIII even employed yet another equivalent expression, "handicapped children".

As in under the Convention and the Charter, the Act has a provision that restricted the enjoyment of rights by disabled children. However, while as already seen in this work, the restrictions are found in two different provisions under the Convention and the Charter; under the Act, the restriction is found in one provision. The single provision states that every person, authority, body or institution that has the care or the responsibility for ensuring the care of a child in need of special protection measures shall endeavour, within the available resources, to provide the child with such assistance and facilities which are necessary for his education, training, preparation for employment, rehabilitation, and recreational opportunities in a manner conducive to his achieving the fullest possible social integration and individual development and his cultural and moral development. ${ }^{1}$

The Act restricted the rights of the disabled child to "available resources" just like the two provisions in the Convention that restricted the rights to "available resources" and "whenever possible"; and the two provisions in the Charter that restricted the rights to "available resources".

Having made a succinct comparison of specific provisions in the rights of the disabled child as set out in the Convention, the Charter, and the Act, this paper shall now dwell on its theme, whether the specific provisions in the Act is a necessity or a surplusage; and what the effect of the specific provisions (if any), is, on the rights provided for the disabled child.

The Need or Otherwise for the Specific Provisions. The express provision for the rights of the disabled child was a manifest show that the framers did not want to take for granted that, the interests of those who are disabled have been accommodated in the Act. The only regrettable circumstance (as can be gleaned from this work) is that the effect of these specific provisions were gravely watered down by the "subject to available resources" clause.

Notwithstanding the unfortunate circumstance, the relevance of this paper is to determine whether it was even necessary for the specific provisions to have been made; and to further determine the effects of the specific provisions (if any), on the rights provided for the disabled child. This paper shall analyse the various provisions of the Act and thereafter venture an answer to the issues for determination.

The relevance of the provisions of the Act for the disabled child is to ensure that the disabled child's survival and development are guaranteed. It is for this reason that the Act pungently made a provision that a child who is in need of special protection measures has the right to such special protection measures as is appropriate to the child's physical, social, economic, emotional and mental needs. ${ }^{2}$ The Act further made a provision that such rights shall be made available to the child under conditions that ensure the dignity of the child, that promotes his self-reliance and

${ }^{1}$ Ibid., section 16 (2). Underlining mine, for emphasis.

${ }^{2}$ Note 21, loc.cit. 
also promotes his active participation in the affairs of the community. ${ }^{1}$ These rights to survival and development of the disabled child have adequately been captured in section 4 of the Act that provides that "every child has a right to survival and development" the phrase "every child" as used in this section is not exclusive of the disabled.

The provisions in the Act at all times employed the word "child" or "children" and in circumstances that show that there exist no intentions of excluding, or that there was an exclusion of the disabled child. The Act was made for the child, not for the non-disabled child. "Child" within the contemplation of the Act includes the disabled child. It never contemplates excluding them. If, as it were, the word "child" includes the disabled, there was no need to make specific provisions for the disabled child when the provisions of the Act without those specific provisions covered the interest of the child, whether disabled or not.

Where a child is disabled, he is not at all disadvantaged by the absence of any specific provisions for him because by the fact of being a child all actions taken by any group, must have his best interest as the paramount consideration. The adequate protection that enures to the child, including the disabled child, is sufficiently captured in the first section of the Act in these words:

In any action concerning a child, whether undertaken by an individual, public or private body, institutions or service, a court of law, or administrative or legislative authority, the best interest of the child shall be the primary consideration.

By virtue of this provision of the Act, the disabled child is entitled to anything that it shall be in his best interest to have. For this reason therefore, there is no need for specific provisions for the rights of a disabled child.

From what has been discovered in this work, the effect of the specific provisions was watered down by the "subject to available resources" clause. By that clause, where resources are not available or are available but not adequate, the disabled child cannot enjoy the specific rights provided for in the Act. Whether or not resources are available or are adequate may become a subject matter of litigation that would last for several years as characterizes litigation in Nigeria. With all these impediments to the realization of the specific rights, one may contend that the specific rights defeated themselves.

What is more, the Convention and the Charter provided for some rights that were not provided for, in the Act. The respective rights are the rights of the disabled, to the benefits of international co-operation; and the rights of the disabled, to equal access to education with all sections of the community. The Convention has this to say:

States Parties shall promote in the spirit of international co-operation the exchange of appropriate information in the field of preventive healthcare and of medical, psychological and functional treatment of disabled children, including dissemination of access to information concerning methods of rehabilitation education and vocational services, with the aim of enabling States Parties to improve

\footnotetext{
${ }^{1}$ Ibid.
} 
their capabilities and skills and to widen their experience in these areas. In this regard, particular account shall be taken to [sic] the needs of developing countries. ${ }^{1}$

The rights set out in the Charter are in these words:

Every child shall have the right to education. States Parties to the present Charter shall take all appropriate measures with a view to achieving the full realization of this right and shall in particular...take special measures in respect of ...disadvantaged children, to ensure equal access to education for all section of the community. ${ }^{2}$

These important rights set out in the Convention and the Charter were not provided for in the Act, which Act has made specific provisions for the rights of the disabled to measures of protection appropriate to their needs, ${ }^{3}$ although subject to available resources. ${ }^{4}$

By the express provision for the right to measures of protection and the exclusion of the rights to benefits of international co-operation; and to education, respectively provided for in the Convention and in the Charter, the ready inference is that the Act never wanted the type of rights provided for in the Convention and in the Charter to be available to the disabled Nigerian child. The maxim has always been expressio unius est exclusio alterius, that is to say, the express mention of a thing is an implied exclusion of another. ${ }^{5}$ In other words, the express mention in the Act, of the right to measures of protection is an implied exclusion of the rights, not found in the Act, for examples, the right to benefits of international co-operation and the right to education as respectively provided for in the Convention and in the Charter. Having provided for the rights to measures of protection, if the Act had wanted to provide for the right to the benefits of international co-operation and the right to education, it would have provided for them, as it did for the right to measures of protection. With the effect of the specific provisions excluding the rights not specifically provided for; and limiting the rights to those provided for, the specific provisions counter the intent and purport of the Act: "The best interest of the child... [being of]... primary consideration". It is obviously not in the best interest of the child, that some rights that should be available to them (e.g. right to the benefits of international co-operation; and rights to education as respectively provided for under the Convention and under the Charter) are not available to them.

With the exclusion of other rights by specific rights, one may contend that the specific rights are counter-productive.

\footnotetext{
${ }^{1}$ Note 15, op.cit., Article XXIII (4).

${ }^{2}$ Note 18, op.cit., Article XI (1); (2); (3) (e).

${ }^{3}$ Note 21, loc.cit.

${ }^{4}$ Note 22, loc.cit.

${ }^{5}$ The Supreme Court of Nigeria in Sun Insurance (Nig) Plc v.UECC Ltd (2015) 11 NWLR (pt. 1471) p. 2 ratio 7. The alternative expressions are inclusio unius exclusio alterius (the inclusion of a thing is an implied exclusion of another) or enumeratio unius exclusio alterius (the enumeration of a thing is an exclusion of another). For these expressions (i.e. expressio unius est exclusio alterius, inclusio unius exclusio alterius and enumeratio unius exclusio alterius) see the Court of Appeal of Nigeria in Oloja v. Governor, Benue State (2016) 3 NWLR (pt. 1499) 217 ratio 5.
} 
Conclusion and Recommendation. So far what has been discovered is that the specific provisions for the disabled Nigerian child have been accommodated by the provisions of the Act which neither struck a distinction between the disabled and the non-disabled nor could by any stretch of imagination be interpreted as not protective of the disabled child. It has further been discovered that whatever right a disabled child contemplates has already been afforded by section 1 of the Act that guarantees that the paramount consideration in all things, is the best interest of the child, which undoubtedly never excluded the disabled. Again, it has also been discovered that the limiting clause in the specific provisions constitute device that can make the realization of the rights in the specific provisions slim.

From all these, the obvious conclusion is that the specific provisions in the Act on the rights of the disabled children are not necessary. Having been covered by the numerous provisions in the Act and the omnibus provision in section 1 of the Act, at best, the specific provisions constitute a surplusage; which surplusage it has been opined (in this paper), is counter-productive.

On account of the discovery that the surplusage is counter-productive, the recommendation is that the specific provisions comprised therein be expunged from the Act.

Айанвачуку M. A., доктор філософії у галузі права, старший викладач, юридичний факультет, Ебонійський державний університет, Нігерія, м. Абакалікі.

e-mail: hemenfaga@gmail.com

Закон про права дітей в Нігерії та права дитини з обмеженими можливостями: необхідність чи надмірність?

Права дитини закріплені в Законі Нігерї про права дітей 2003 року. Цей Закон містить конкретні положення щодо прав дитини з обмеженими можливостями. Автор статті піддає критиці актуальність цих положень в світлі інших законодавчих актів Нігерії. Аргументовано, що иі положення є надлишковими і непродуктивними, тому вони мають бути вилучені.

Ключові слова: права дітей; дитина з обмеженими можливостями; Нігерія; міжнародні нормативні акти.

Надійшла до редколегії 20.08.2017 р. 